Article

\title{
A Typology Framework for Trade-Offs in Development and Disaster Risk Reduction: A Case Study of Typhoon Haiyan Recovery in Tacloban, Philippines
}

\author{
Heidi Tuhkanen 1,2,*(1), Michael Boyland ${ }^{2,3}$, Guoyi Han ${ }^{2,4}$, Anjalee Patel ${ }^{5}$, Karlee Johnson 2,3, \\ Arno Rosemarin 4 (iD) and Ladylyn Lim Mangada ${ }^{6}$ \\ 1 Stockholm Environment Institute, Tallinn Centre, Tallinn 10416, Estonia \\ 2 International Centre of Excellence on Transforming Development and Disaster Risk, Stockholm \\ Environment Institute and Integrated Research on Disaster Risk (IRDR) Programme, Bangkok 10330, \\ Thailand; michael.boyland@sei.org (M.B.); guoyi.han@sei.org (G.H.); karlee.johnson@sei.org (K.J.) \\ 3 Stockholm Environment Institute, Asia Centre, Bangkok 10330, Thailand \\ 4 Stockholm Environment Institute, Stockholm Centre, Stockholm 10451, Sweden; arno.rosemarin@sei.org \\ 5 Faculty for Social Science and Public Policy, King's College London, Strand, London WC2R 2LS, UK; \\ anjalee07.patel@gmail.com \\ 6 Division of Social Sciences, UP Visayas Tacloban College; Tacloban City 6500, Philippines; \\ llmangada1@up.edu.ph \\ * Correspondence: heidi.tuhkanen@sei.org; Tel.: +358-44-575-0259
}

Received: 29 April 2018; Accepted: 4 June 2018; Published: 8 June 2018

\begin{abstract}
Development and disaster risk are deeply linked. Disasters reverse development gains; development initiatives influence the risk, vulnerability, and exposure of people, assets, and environments to disasters. Hence, knowledge of key dimensions of the potential trade-offs between development and disaster risk reduction (DRR) may inform decision-making processes, goals, and initiatives in ways that have potential to address unsustainable development practices that are commonplace in countries of all economic levels. This paper presents, explores, and tests a conceptual framework for analysing the trade-offs that underpin this relationship as evidenced through policy goals, initiatives, and decision-making processes. We categorise key dimensions of relevant trade-offs into five specific dimensions: (i) The aggregation of development and DRR gains and losses, (ii) risk prioritisation when seeking to reduce multiple risks, (iii) the equity of decision-making processes and outcomes, (iv) the balancing of near- and long-term goals, and (v) the distribution of power and participation. By framing key questions related to each trade-off dimension, we test the framework in the context of a major disaster recovery process in Tacloban, the Philippines, following Typhoon Haiyan (Yolanda) in November 2013. We consider how decision-making trade-offs can be made more visible and useful in the pursuit of transformative change in development and DRR.
\end{abstract}

Keywords: development; disaster risk; DRR; trade-offs; Typhoon Haiyan

\section{Introduction}

Development and disaster risk are deeply linked. Disasters destroy assets, entrench poverty, and reverse development gains, while development initiatives influence disaster risk, vulnerability, and the exposure of people, assets, and environments. Risk is an unavoidable aspect of development, but there is a threshold of tolerable and acceptable risks-linked with the capacity to manage the risks knowingly taken on-and exceeding that threshold can cause disasters. 
Scientific knowledge of the relationship between development and disaster events is wide-ranging and extensive. As early as 2001, White et al. [1] considered that disasters are increasingly understood as being embedded in development processes and tied to goals of reducing poverty and inequity, improving governance, and limiting climate change. The Sendai Framework for Disaster Risk Reduction (Sendai Framework for DRR) — the global policy framework for reducing disaster losses and risks-identifies the same (among many) development-oriented factors as root causes of disaster risk that must be tackled to prevent the creation of new risks [2]. Historically, disaster risk reduction (DRR) policy and practice have largely focused on managing disaster events and associated losses through coping and response action (i.e., ex post). While we have seen progress in disaster prevention and DRR mainstreaming in recent years, there is still insufficient knowledge of the underlying drivers of risk. Greater knowledge of these risk drivers is imperative for proactive DRR policy [3].

Numerous studies, spanning local to global scales, have illustrated the complex, intertwined relationship between development and disaster risk. The massive social and economic losses in Central America following Hurricane Mitch in 1998 have been tied to the unsustainable economic growth policies that drove up vulnerability and reduced resilience through infrastructure development on floodplains, deforestation, and the marginalisation of smallholder farmers [4,5]. Globally, similar patterns are increasingly blamed for major disasters, for instance, the 2011 floods in Thailand and changes in seasonal flood regimes in the Mekong Delta [6].

In terms of social inequality, disasters typically disproportionately impact women, children, the elderly, and people with disabilities [7-10]. The root causes of these inequalities lie in biased social norms, exclusionary power structures, and the absence of the most vulnerable citizens from DRR and development planning and action. Overall, reviews have shown that disasters reverse economic and human development gains, and disproportionately so in developing countries [11-13].

Development is a double-edged sword for disaster risk; acting to both increase and decrease risk, depending on the development intervention, its context, and scale. The 2030 Agenda for Sustainable Development embeds DRR-related targets in several sustainable development goals (SDGs) [14]. However, unsustainable development pathways, typically characterised by rapid and unplanned urbanisation, and natural resource degradation, evidence the need to transform the predominant "risk-driving" relationship between development and disaster risk [15].

One possible entry point into this issue is to examine the trade-offs within and between development and DRR decision-making processes. Trade-offs, defined as decisions involving diminishing or losing one quality or desirable outcome in return for gaining another, are inherent in situations where multiple objectives, stakeholders, scales, and/or time-horizons collide. Trade-offs have been explored in a wide variety of fields: Finance [16], business [17], as well as land-use planning and management [18-20]. The identification and negotiation of trade-offs and competing interests is also intrinsic to the pursuit of SDGs [21,22]. For instance, it has been shown how hydropower development-often considered as the engine for renewable energy growth-is capable of directly increasing flood and drought risks, as well as other negative environmental and livelihood-related consequences, in the Mekong region [23,24]. A broad trade-off between economic growth and disaster risk is inherent [25], but there is a need for more nuanced analysis of trade-offs in realms of development and disaster risk decision-making.

Against this backdrop, the overarching aim of this paper is to explore the relationship between development and disaster risk through the lens of trade-offs. To this end, we present a new conceptual typology of key dimensions of the trade-offs between development and DRR goals, initiatives, and decision-making processes; we test the validity of the typology in the context of a major disaster recovery process in Tacloban, the Philippines, following Typhoon Haiyan (Yolanda) that struck in November 2013. This typology provides an organising framework that unpacks and articulates key dimensions of the trade-offs in decision-making processes; it also poses critical questions for deeper exploration of each dimension. The five key dimensions articulated and tested are: (i) Aggregation of development and DRR gains and losses, (ii) prioritisation of risks when seeking to reduce multiple 
risks, (iii) equity of decision-making processes and outcomes, (iv) balancing of near- and long-term goals, and (v) distribution of power and participation.

The losses and risks associated with disasters continue to increase, despite a substantial body of scientific evidence and wide acceptance that development processes strongly influence disaster risk creation and accumulation. This implies the existence of significant barriers that are preventing knowledge from effectively transferring to policy (planning) and practice (implementation). White et al. [1] posit that knowledge uptake lags behind the rapid pace of the rise in societal risks (driven by poverty, inequality, and population growth). Articulating a typology of development and DRR trade-offs, and exploring how decision-makers might proactively navigate them, may lead to better understanding of the barriers in existing decision-making practices and to better alignment of the two, often disparate, processes. Specifically, the trade-offs lens and framework take DRR interventions upstream to the decisions and processes shaping development's influence on risk, and vice versa. Understanding and re-framing trade-offs in decision-making may provide an entry point for transforming the current "risk-generating" development-disaster risk relationship and for integrating DRR with equitable, resilient, and sustainable development.

\section{Methods}

First, we conducted a non-systematic review of scientific literature, grey literature, and policy and planning documents relevant to development and DRR. The review assessed the extent to which the literature considers trade-offs, and the typology framework was developed from explicit, implicit, and constructed considerations and examples of trade-offs. Explicit trade-offs used the term 'trade-off' to describe two issues that represented misalignment between development and DRR. Implicit trade-offs described a trade-off situation, but did not use the term. Constructed trade-offs were created by the authors using evidence and examples from multiple sources of literature. A search of scientific literature, performed with the Scopus and Google Scholar search engines, used various versions of the search term 'trade-off' (i.e., trade-off, tradeoff, and trade off). Citations within search result articles garnered further literature. The examples under each dimension are derived from the literature review and, so, it is expected that additional examples not identified here will exist. We developed key questions to explore each of the trade-off dimensions that constitute the typology framework, and to, potentially, identify additional trade-offs, for the application of the framework within a given context.

Second, we tested the trade-off typology framework in a post-disaster (Typhoon Haiyan/Yolanda) recovery and redevelopment context in Tacloban City, Philippines. The testing sought to validate the framework by gathering empirical evidence on the decision-making processes directly related to post-disaster recovery and redevelopment efforts at the city level. We conducted two rounds of semi-structured key-informant interviews in 2017 with representatives from: (i) National- (interview code: NG), regional- (interview code: RG), city- (interview code: CG), and local-level (interview code: LG) government offices; (ii) INGOs (interview code: INGO), NGOs (interview code: NGO), and intergovernmental organisations (interview code: IGO); and (iii) homeowners associations (interview code: HA) and residents in the resettled areas (interview code: R). The first round of interviews gathered data on the decision-making and planning process, the second round on project implementation, monitoring, and evaluation.

A total of 41 interviews were conducted. In six cases, two different individuals from the same government department or organisation were interviewed to gain different perspectives (e.g., on planning processes and on project implementation). Of the 41 informants, two individuals were interviewed in both rounds of data collection, but are treated as separate data points. In both rounds, interview questions addressed each trade-off dimension and the most relevant key questions connected to each dimension. Relevance was determined through analysis of the central policy document for the City's recovery-the Tacloban Recovery and Rehabilitation Plan (TRRP), and other literature and documents relating to the disaster recovery, as well as previous interviews. Data collection tools (i.e., interview question guides) were, subsequently, developed to respond to the most relevant key 
questions. This initial pilot test of the framework is expected to inform further development and refinement of the framework and methodology.

\section{A Typology Framework for Trade-Offs in Development and DRR}

Better understanding of the trade-offs between development and DRR goals, initiatives, and decision-making processes offers potential to advance mutually desirable development and DRR outcomes of equity, resilience, and sustainability. Here, we present a typology to unpack trade-offs, organised along five key dimensions: Aggregation, risk, equity, time, and participation.

Each trade-off dimension can be further explored by posing and responding to key questions that reflect the interlinked nature of the trade-off dimensions (see Table 1). By first identifying the aggregated gains and losses resulting from decisions and interventions, one can discern: (i) How those gains, losses, and related risks are accounted for and distributed spatially, temporally, and across social groups, and (ii) the distribution of power and participation in the decision-making processes from which the gains and losses are constructed and evaluated.

\subsection{Aggregation}

The aggregation dimension encompasses the trade-off between the gains and losses of development and DRR decision-making and action. Typically, gains are desired, anticipated, and explicit to planning processes, while losses tend to be unintended, unanticipated, and implicit. Insured and uninsured economic losses from disasters are increasing globally; 2017 was the second costliest year (US\$330 bn), second only to 2011 (US\$354 bn) [26]. In absolute terms, economic losses from disasters are concentrated in wealthier countries, but, relative to national GDP, disaster losses are worst for low-income countries. Small-scale disasters, in particular, regularly erode essential services, infrastructure, and assets in poorer countries that struggle to maintain development gains and investments [15].

A key consideration in this dimension concerns trade-offs between DRR and other competing aims or needs. Public resources are finite and are typically stretched thin, especially in times of low economic growth [27]; households must also decide whether to allocate resources to basic needs, luxuries [28-30], or risk reduction measures, such as insurance [31]. The cost of living, housing prices [32], livelihood opportunities [33], and the availability of affordable insurance can all influence people's decisions to live in risky, hazard-exposed areas, as well as how to invest in disaster protection [34]. Also, non-financial factors, such as attachment to a place and community [35,36], and place-based culture [37], can make people want to remain in a place that is hazard prone. Understanding personal and collective prioritisation is a necessity for devising mechanisms that incentivise protection and risk aversion.

A main goal that can compete with DRR is economic growth or gains. Competition for financial and human resources occurs between and within development and DRR sectors [25], but the two, as overarching goals, can also be at odds with each other at all decision-making scales [33,38-41]. Assessing the implicit trade-offs in investment decisions may explain who bears the risks and costs, who receives the benefits, and why DRR investments are de-prioritised in favour of "risky", but potentially profitable, investments [15].

Indeed, the correlation between disaster-prone and profit-generating areas (such as, floodplains, deltas, and low-lying coastal areas that attract people and investment) shows impending or inevitable losses to be overlooked. For example, in low and middle income countries, where regulations, such as building codes, are not uniformly followed, rapid growth is less likely to be risk-informed or resilient to future stresses [42]. Thus, targeted DRR initiatives can be perceived as a limitation on growth or as a barrier to investment. In other cases, private investments can be seen as an opportunity for long-term risk reduction. For example, there is evidence of local authorities in developed countries encouraging development projects in flood-prone areas as a strategy to generate revenue in order to finance large-scale flood protection projects in the future, highlighting the potential complementarity of achieving development and DRR objectives [43]. However, under a strict economic-growth approach, 
the prioritisation of DRR investments will likely only occur if the benefits clearly outweigh the costs. Yet, cost-benefit analysis does not account for indirect benefits [15], such as avoided social and environmental losses [37]. The "hidden" nature of avoided losses poses a threat to major investment in DRR [25]. Further, data to demonstrate how investments reduce the economic impact of disasters are lacking $[25,44]$.

\subsection{Risk}

The risk dimension defines the trade-offs made between the different, often interlinked, risks. The likelihood of an event, and the magnitude of its consequences (both of which are, by definition, uncertain), determine risk levels [45]. Multiple and changing factors of uncertainty make prioritising between different risks challenging [46].

The risk trade-off dimension concerns how different risks are weighed and prioritised, and how that impacts DRR or development decisions. Decision makers prioritise between myriad disaster risks [25,47,48], non-disaster-related risks [49], and overall resilience [47,50-52]. In dealing with multiple risks, decision makers must also choose between investing in mitigation, prevention measures, or insurance coverage [33]. Similarly, insurance providers and public authorities must decide how to maximise both mitigation and coverage [34].

While most of the literature on risk interpretation and decision making is limited to single-hazard risks [45], the reality is more complex and globally interrelated [25]. For example, risks can be categorised as intensive ("high-severity, mid to low-frequency disasters") or extensive ("low-severity, high frequency disasters") [15]. Multi-hazard events include potential interactions between several hazards in a particular location [53]. Reducing a risk for one social group or community, or in one location, can mean negative consequences for others elsewhere [54]. Risk models and decision-makers face challenges in dealing with multiple types and the cascading effects of risks $[25,27,46]$.

Another challenge is that risks are prioritised based on societal norms [15,55], beliefs, values, awareness among actors, trust in others, and how people deal with uncertainty [45]. Policy-makers should account for the ways individuals prioritise disaster and other risks, such as those related to access to basic needs [49,56] and the potential loss of community, social networks, and livelihoods [57], which individuals and communities have sometimes prioritised over disaster risks. Nathan [56] urges understanding of the context, rather than labelling the failure to prioritise disaster risk as illogical $[45,56]$ or ignorant $[45,49]$. When policy-makers can neither predict nor understand how citizens relate to disaster risk, government-led interventions fail to reduce disaster risk [58]. Roberts [57] also challenges researchers to seek public validation of research assumptions and to recognise peoples' local expertise.

\subsection{Equity}

The equity dimension addresses the trade-offs in the distribution of the risks, benefits, and losses from development and DRR decisions. The definition of equitable as "fair and impartial" [59] is subjective. However, decision-making that drives inequity in society is not aligned with either resilience [60] or sustainable development [61]. The current global neo-liberal economic model is, simultaneously, seen as a solution to global poverty, as well as a cause of continued inequity [58] and increased vulnerability [62]. While this model of economic growth may bring economic opportunities to marginalised populations, it requires social participation to have a positive impact on equity [63]. Societal participation is a challenge for the vulnerable [64]. Rigg and Oven [62] claim that the trade-off between market led economic development and resilience is ignored, at least partially, because it challenges the prevailing system.

A trade-off between equity and equality—-between providing differentiated needs-based support and equal treatment-may emerge in the allocation of resources and support following a disaster. This trade-off is particularly relevant to cultural contexts where either equitable or equal treatment of people is valued by society [65]. In the insurance industry, a trade-off surfaces between affordable, widespread 
coverage, which is in the interest of the government and potential policy holders, and risk-based pricing that incentivises risk reduction, which is in the interest of the insurance industry [34].

In the context of planning insurance mechanisms, policy-makers confront the trade-off between equity and efficiency in allocating limited resources to support DRR measures and dealing equitably with residents confronting insurable losses [66,67]. Affordable insurance, designed to protect residents located in areas exposed to natural hazards, can create disincentives for DRR measures [27,34] and drive up disaster costs, though these effects can be curbed by making insurance conditional on private DRR measures [27]. This trade-off also covers the question of how to support those who have significant uninsured losses without incentivising people to do without insurance.

Disaster risks accumulate through numerous public and private decisions, and are often transferred to those who have not been involved in the decisions [38]. The poor, who are seldom insured for disaster, experience disproportionate impacts through loss of assets [68], income, and consumption capacity, which can also lead to health impacts [69], displacement, and a weakened coping capacity.

Thus, better consideration of equity-related trade-offs requires an understanding of the social groups at risk, which may include persons without status, power, or wealth $[15,69]$, informal settlers, those working in the informal sector [70], marginalised ethnic and racial minorities, women, children, the elderly, or those otherwise disadvantaged in a particular situation [71]. Hallegatte et al. [68] argue that, to make the largest improvement in well-being, DRR measures, coupled with measures to increase socio-economic resilience, should prioritise the poor and the vulnerable.

\subsection{Time}

The time dimension deals with the balancing of current and future opportunities, threats, risks, and needs. When the potential costs from future disasters and the potential future benefits from DRR are significantly discounted [15], short-term gains can come at the expense of increased disaster risk, which is often not apparent until later. Especially, low-frequency hazards, which may occur far in the future, tend to be overlooked in favour of high short-term returns on capital [38]. Investment decisions tend to consider the comparative advantages of a specific location, while potential liabilities tend to be ignored [15,38] and unaccounted for in capital investment decisions [72].

Increasing development occurring in hazard-prone areas all over the world illustrates the issue [46]. Despite the considerable risks from hurricanes, coastal storms, and sea-level rise, cities, such as Miami, attract high- value, long-term-insured infrastructure investments. While Miami is making significant investments to mitigate disaster damage [73], investments in high-risk areas, nonetheless, contribute to higher overall disaster losses [25]. In developed countries, this trend, underpinned by government-backed insurance policies, puts an increasing burden on the public sector in the long term [25].

This dimension underscores the potential political costs of making long-term decisions related to DRR $[46,74,75]$. Politicians, whose careers depend on the next election's results, face pressure to prioritise short-term needs [74]. Furthermore, disaster-response situations generate urgency; by contrast, taking steps to avert or reduce disaster risk entails uncertainty over the necessity of steps, such as drought mitigation measures limiting water use. Politicians may also not receive credit for policies that avert potential disasters [75].

Another temporal trade-off occurs between the need for immediate disaster response and the management of decision-related risks. When processes speed up, less financial monitoring takes place, and financial risks related to corruption or misuse grow [76]. The public sector faces pressure to reduce regulations to enable quick recovery [77]. Thus, the rapid planning and implementation necessary in post-disaster recovery can trump comprehensive planning and fiduciary risk management. 


\subsection{Participation}

The participation dimension deals with the degree and nature of stakeholder involvement in decision-making and how power is shared. The disaster-related decision-making process takes place in an arena where actors, such as investors, insurance companies, and governments, negotiate their perceived trade-offs based on their competing interests [34,38]. However, to reduce overall disaster risk levels, stakeholders need to cooperate and identify shared value through which shared benefits are created. This requires the recognition of actor interdependence [38].

In the context of flood risk management in China, Han and Kasperson [40] identify the trade-off between actor cooperation and competition, and highlight the need for the institutional capacity to enable stakeholder coordination required for successful flood risk management [40]. In China, economic processes which drive competition, such as decentralisation, market reform, and privatisation, as well as an increase in social inequality between and within regions, have made cooperation for flood risk management difficult to achieve [40].

Institutional capacity to enable cooperation and participation links with the potential trade-off between efficient participation and effective participation. Participation can reduce risks, but involvement of the appropriate stakeholders, such as local and national governments, civil society, and the local communities [78], especially marginalised communities, requires resources, time, skills, and funding. These resources may not be available or may fail to win needed support, particularly when emergencies demand quick action $[79,80]$.

However, planning without appropriate participation can lead to measures that fail to support recovery $[80,81]$ or have unintended negative consequences on development $[79,82,83]$. After reviewing post-disaster reconstruction processes in ten countries, Schilderman and Lyons [84] concluded that, while top-down, donor-driven recovery processes resulted in technically safer housing, the process failed to support overall resilience. A lack of community involvement in resettlement decisions can lead to policies made on false assumptions, leaving community residents to choose between returning to hazard-prone areas or struggling with poorly met needs in a new location [79].

Participation also requires political will [85]. Decisions and decision-making processes are a matter of power relations [6,37]. Broadening participation, inevitably, means shifting the power balance to some degree and, thus, creating a trade-off between power and participation. Participation is seen as opening up space for transformation and questioning the status quo [85], established norms, institutions, and development paths [58]. 
Table 1. A typology framework for trade-offs in development and DRR.

\begin{tabular}{|c|c|c|}
\hline $\begin{array}{l}\text { Trade-Off Dimension and } \\
\text { Definition }\end{array}$ & $\begin{array}{l}\text { Examples of Trade-Offs and How } \\
\text { They Were Constructed }\end{array}$ & $\begin{array}{c}\text { Examples of Key Questions to Explore Each } \\
\text { Dimension }\end{array}$ \\
\hline $\begin{array}{l}\text { Aggregation: The } \\
\text { aggregation of } \\
\text { development and DRR } \\
\text { gains and losses }\end{array}$ & $\begin{array}{l}\text { - Competing needs vs. DRR [34] } \\
\text { (E) } \\
\text { - Economic gain vs. DRR [39] (E) }\end{array}$ & $\begin{array}{l}\text { What are the goals and needs, and how are they } \\
\text { defined?What are the losses, and are } \\
\text { they anticipated? } \\
\text { - How are gains and losses measured or quantified? }\end{array}$ \\
\hline $\begin{array}{l}\text { Risk: The prioritisation of } \\
\text { risks when seeking to } \\
\text { reduce multiple risks }\end{array}$ & $\begin{array}{ll}\text { - } & \text { Reducing one risk vs. another } \\
& \text { risk [62] (E) } \\
\text { - } & \text { Individual DRR vs. general } \\
\text { system resilience [47] (E) }\end{array}$ & $\begin{array}{l}\text { What are the known risks (hazard and non-hazard } \\
\text { related)? } \\
\text { - How are individual risks interrelated and linked to } \\
\text { general system resilience? } \\
\text { - How is managing/reducing risks prioritised? } \\
\text { risk assessments? }\end{array}$ \\
\hline $\begin{array}{l}\text { Equity: The equity of } \\
\text { decision-making processes } \\
\text { and outcomes }\end{array}$ & $\begin{array}{ll}- & \text { Equity vs. equality [65] (E) } \\
- & \text { Equity vs. efficiency [66] (E) } \\
- & \text { Market led economic } \\
\text { development vs. resilience [62] } \\
\text { (E) }\end{array}$ & $\begin{array}{l}\text { - How equitable is the distribution of } \\
\text { expected/desired gains and anticipated losses? } \\
\text { To what extent are impacts on vulnerable and/or } \\
\text { marginalised groups in society } \\
\text { explicitly considered? } \\
\text { - To what extent does the economic development } \\
\text { pathway influence equity and resilience? }\end{array}$ \\
\hline
\end{tabular}

Table 1. Cont.

\begin{tabular}{|c|c|c|}
\hline $\begin{array}{l}\text { Trade-Off Dimension and } \\
\text { Definition }\end{array}$ & $\begin{array}{l}\text { Examples of Trade-Offs and How } \\
\text { They Were Constructed }\end{array}$ & $\begin{array}{c}\text { Examples of Key Questions to Explore Each } \\
\text { Dimension }\end{array}$ \\
\hline $\begin{array}{l}\text { Time: The balancing of near } \\
\text { and long-term goals, costs, } \\
\text { and benefits }\end{array}$ & $\begin{array}{l}\text { Pursuing short-term vs. } \\
\text { long-term aims [15] (I) } \\
\text { Immediate disaster response vs. } \\
\text { intervention risk } \\
\text { management [76] (E) }\end{array}$ & $\begin{array}{l}\text { - What time-frames for goals, costs, and benefits are } \\
\text { being considered and what takes priority? } \\
\text { - What are the potential impacts beyond } \\
\text { the time-frame? } \\
\text { - How compatible are short- and long-term goals, } \\
\text { gains, and losses? } \\
\text { How compatible are proactive and reactive plans } \\
\text { and goals? } \\
\text { Are future costs and benefits } \\
\text { appropriately discounted? }\end{array}$ \\
\hline
\end{tabular}

To denote how the trade-off example was constructed, each example from the literature is followed by a notation of whether it was explicitly stated (E), implicitly described (I), or constructed from more than one piece of literature (C), as is noted in the methods section.

\section{Testing of the Trade-Off Typology Framework in Tacloban, Philippines Following Typhoon Haiyan (Yolanda)}

On 8 November 2013, "super" typhoon Yolanda (international name, Haiyan), one of the strongest and deadliest tropical cyclones recorded, struck the Philippines. The Eastern Visayas, home to 31\% of the affected people and $43 \%$ of the damaged houses, suffered the greatest human and economic losses [86]. 
In Tacloban City, the highly urbanised regional hub of the Eastern Visayas, at least 6000 residents died and more than 30,000 houses were destroyed [87]. In the six months following the disaster, the City government and UN-Habitat (United Nations Human Settlements Programme) led the planning for the rehabilitation and recovery, which resulted in the adoption of the TRRP [88]. The TRRP envisions a resilient, vibrant, and livable Tacloban, with the recovery viewed as an opportunity to address development challenges and to "build back better". From a research perspective, the post-disaster period offered an opportunity to empirically test the trade-off typology framework, as outlined above. The analysis below reflects the trade-offs that emerged from our interviews.

\subsection{Aggregation}

4.1.1. What Were the Main Goals and Did Any of the Goals Conflict in a Way that Attainment of One Would Negatively Affect Others?

The central planning document for the recovery in Tacloban, the TRRP, served as, "the roadmap that identifies the immediate actions and operational strategies that will lead Tacloban and its people towards recovery, rehabilitation, and sustainable development after Typhoon Yolanda" [88]. The TRRP consists of five sectoral plans: Shelter (i.e., provision of new housing), social services (i.e., restoration of health, education, social welfare, and peace and order), economic (i.e., increase of productivity, diversity, business security, and food security), physical infrastructure (i.e., resilient repair and rehabilitation of infrastructure), and environment (i.e., coastal protection, water resources, waste management, land use planning, and early warning systems).

A six-month consultative planning process orchestrated by the Tacloban Recovery and Sustainable Development Group (TRSDG) defined the recovery goals. The TRSDG, led by the City government (chaired by the Mayor) in partnership with the UN-Habitat (co-chair), engaged government agencies and other stakeholders through planning workshops and meetings. The core planning team established coordinators and secretariats for each of the five TRRP sectors. A central aspect focused on planned construction of new housing and relocation of $40 \%$ of the City residents, with a focus on poor residents who had lived in informal settlements on the coast, mostly to North Tacloban (CG9, HA2). Improved safety and reduced typhoon and storm surge disaster risk for residents were the primary goals and expected gains of the relocations (CG9, CG14, HA2).

The potential losses, or the "negative impacts", which could have resulted from recovery interventions, are not reflected in the TRRP document itself, demanding an analysis of empirical data to understand the extent to which losses were anticipated in the planning process. Various losses, some of which were not anticipated beforehand, were identified by interview informants who now had a retrospective view of the post-disaster decision-making processes. The, still ongoing, relocation of tens of thousands of people required building thousands of new homes, mostly in North Tacloban. While many households gained new and improved permanent housing away from danger, several infrastructure challenges emerged, most significantly, the lack of piped water (CG1, CG3, CG5, CG14, LG1, NG2). City government tankers deliver water to relocation sites daily, although some residents must purchase from privatised sources to meet their needs (HA2). Limited sewerage and poor solid waste management affect some relocation sites, leading to flooding and sanitation concerns (INGO6, HA2).

The lack of basic service provision is due to long-standing political differences between city and provincial governments that have budgetary authority over the water-supply project, disagreements over responsibilities of basic services provision (CG9), and on "failure of bidding" to find suitable project contractors (INGO6, CG5).

By late 2016, three years after Yolanda, only some 1,500 families had been relocated. President Duterte's administration ordered an immediate acceleration, and by 2017, 10,000 families had been relocated. Some felt this rushed process ignored the original prioritisation of beneficiaries (INGO1), led to poorer housing quality (LG1), and overlooked important social preparation, which may have facilitated community acceptance of relocation (CG12, CG13, CG14). Further, the scattering of 
pre-Yolanda communities among relocation sites led to the loss of social networks and cohesion (CG12, CG14, R1).

Despite the range of desired goals across different sectors outlined in the TRRP, the City's priority has been the physical safety and reduced exposure to typhoon and storm surge risk of its residents. Large-scale housing construction for the resettlement of coastal communities was seen as the primary means to achieve this goal. All other goals were expected to support or feed into achieving the primary goal. However, coordination of different goals and sectors appears to have been superficial and the reality was that different actors responsible for specific goals pursued their own needs and priorities. While the City Mayor and a few individuals overseeing each of the sectors were responsible for ensuring no conflicts or negative consequences occurred during the recovery process, exactly how potential conflicts were anticipated, evaluated, or prevented is not clear. Avoidable losses of the large-scale housing construction and resettlement, largely due to poor coordination and conflicting interests, have emerged as a result.

4.1.2. Do DRR Measures Conflict with Goals of Economic Growth and Development and, if So, How Are These Conflicts Addressed?

The City's purchase of large agricultural lands-which were previously envisioned as an Eastern Visayas Agri-Industrial Growth Center (CG14) — and rezoning them as relocation sites has displaced farmers who had previously inhabited these areas (CG9). This has pushed some farmers out of their agricultural livelihoods and reduced local agricultural outputs (CG1, CG6, CG10), leading to concerns over future food security (IGO1, INGO6, CG10). These losses resulting from TRRP initiatives suggest that goals did conflict, for instance, the goals of increasing food security and providing new houses.

The lack of livelihood opportunities was an issue for the resettled (CG1, CG3, CG5, CG12, R1, NG1, NGO1, INGO5, RG2). Many families intended for relocation had long relied on fishing for their livelihoods. Moving to North Tacloban, far from coastal fishing areas, created a barrier to accessing that livelihood opportunity. While provision of alternative livelihoods and other economic opportunities was outlined as a major goal of the recovery plan, some felt this was insufficiently considered in the relocation plans (CG10). Pre-existing livelihood programmes, rather than adapting to the new post-Yolanda needs, simply expanded without careful feasibility assessment (CG18, RG2). Also, training programmes, such as on carpentry skills, provided people with skills and income in the short-term, while their local area was being developed (NGO1, CG3), but did not necessarily lead to further employment opportunities (R1). In another case, trainings on farming livelihoods were conducted, but the limited land available curtailed its viability as a livelihood option (INGO5). Although regular cluster meetings were held to ensure livelihood security in the relocation sites, there was limited consultation with community members on the types of livelihood trainings to be given (INGO5). Overall, the alternative livelihoods were deemed inappropriate, ineffective, and unsustainable by both residents and local and city officials (CG5, LG2). This led some people, mainly men, to travel regularly back to San Jose-the fishing area-or to abandon their new units altogether by moving back to the coast in favour of access to jobs in the fishing industry (CG14). Future plans for an industrial economic zone in the North could have attracted some people to the area, but as the plans for relocation moved ahead first, there continues to be issues with employment (CG10).

\subsection{Risk}

What Are the Known Risks and How Are They Prioritised for Risk Reduction?

The TRRP, which considers DRR as a cross-cutting aspect of the plan, called for a City Disaster Risk Reduction and Management Plan (CDRRMP) to take into account lessons learned from Yolanda and the recovery process. A Tacloban CDRRMP was approved in 2016, and covers the period to 2022. Risk, hazard, and vulnerability assessments for Tacloban were intended to be included in TRRP activities and informed the "no-build zone" in downtown coastal areas where informal settlers lived 
pre-Yolanda (CG10). The current CDRRMP considers and maps the following natural hazard risks: Typhoon, earthquake, tsunami, storm surge, flood, landslide, liquefaction, and drought. The Plan also lists biological (water, vector-borne, and preventable diseases) and technological (industrial accident, fire, gas explosion) risks. Further, it recognizes the projected increases in temperature, precipitation, and climate-related extreme events due to climate change.

In the relocation sites, risk assessments identified landslide, flooding, and liquefaction risks, which were minimised using hard infrastructure measures and the areas were deemed safe to inhabit (CG9, CG12). While relocation sites are viewed as significantly safer than the coastal zones (RG2), some communities, relocated to safety from typhoon risks, now face risks from hazards, such as floods and landslides (CG12, LG2, R2). A city government inter-departmental planning team that included outside agencies assessed and prioritised risks (CG8). However, one city government representative claimed that some of the relocation sites are yet to be assessed for risks (CG1), thus, the full extent of disaster risks in this area is unknown.

The overarching priorities of the TRRP are to recover from the effects of Typhoon Yolanda, and, in the process, to reduce overall disaster risk, and to build resilience. More specifically, the TRRP considers "safety of the population" (p. 15) a key consideration for the future development. Some feel that reducing exposure to typhoons and storm surges by mass relocations took priority over minimising social and economic risks, i.e., through lost livelihoods, food insecurity, and lack of water and electricity services, and fragmented social networks (CG10, CG14, RG2). Household- and individual-level priorities may have differed from the priorities resulting from the risk assessments conducted by the city-led planning team, instead prioritizing access to familiar livelihoods, higher quality social services (e.g., schools) and infrastructure, and proximity to downtown areas of Tacloban (INGO7, HA2, R4, CG5). How individuals and households manage and prioritise risks within their own, often economically insecure, contexts could be better understood and accommodated for within city planning processes.

Results show that a range of hazard and non-hazard related risks were identified and prioritised. The impact of Typhoon Yolanda appears to have heavily influenced risk perception, with typhoon risk prioritised perhaps at the expense of reducing other risks, such as floods, landslides, and climate change-induced temperature and precipitation changes.

\subsection{Equity}

On What Basis Were Gains and Losses Distributed and to What Effect?

The TRRP was intended to be guided by the principle of needs-based assistance that is, "considerate of both pre- and post-disaster realities" (p. 5), implying an intention of equitable distribution of benefits. The TRRP planning process and output documents explicitly consider the needs of some specific societal groups, namely women and children, but largely under the social services sector (i.e., health and education) (CG8). Priority for housing allocation went to informal settlers and the urban poor who were most affected and had resided in, what is now designated, a "no-dwelling" zone. Housing recipients were selected according to where they had lived at the time of Yolanda, as well as their family situation; priority went to single-headed households, people with disabilities, pregnant women, and families with many children (CG13).

Despite the intention for equitable distribution of gains and a prioritisation of those most in need, some received benefits due to political patronage, connections, and biases (R1, INGO1). Lobbying of local officials and timing of requests influenced the distribution of benefits and national-level disbursements, which may or may not have been based on need (CG5, NG2). This resulted in duplication of support for some, particularly those with close political or personal connections with local officials, while other intended beneficiaries received little to no support (CG9, CG12, HA2). Community assertiveness also influenced the level and timing of NGO and government support 
(NGO1). The City Housing Board is now taking actions to evict people who received housing, but were not on the initial list of beneficiaries (CG10).

Government and NGOs providing housing did not always coordinate among themselves who would be receiving houses, nor did they use the same metrics for deciding who was eligible for housing (CG9). While most organisations intended to respond to the needs of the most affected or needful, implying an equity-based approach, there were differences in approaches to distribution. For example, the emphasis on relocation of informal settlers led other residents to feel overlooked (INGO6), thus, some NGOs also targeted assistance for the "host communities" - those households that provided temporary shelter in the aftermath of the disaster-that were burdened by the relocation process (INGO6, LG2).

\subsection{Time}

4.4.1. What Were the Time-Frames Related to Goals and How Compatible Were Short- and Long-Term Goals?

The TRRP is considered both a DRR and development plan (CG9, CG12); with the vision of early recovery projects laying the foundations for long-term development (CG14). It is expected "early recovery projects (shelter, livelihood, infrastructure restoration)" to be completed within three years and "longer term developmental projects" to be implemented between three and nine years after Yolanda. Within the TRRP document, there is no noticeable conflict between short and long-term goals.

The short-term phase for shelter involves the construction of permanent, resilient houses with appropriate conditions supportive of resettlement in low-risk/disaster-free areas (within one year) and a township with appropriate support facilities (within three years). The long-term vision is one of Tacloban City as a global model of a livable and climate-resilient city (within nine years). In the economic development plan, the recovery phase (one to three years), focuses on restoration and revitalisation of the local economy, including construction and livelihoods, while the redevelopment and growth phase (four to nine years) focuses on economic growth and competitiveness. The TRRP was also expected to be fully integrated into the Comprehensive Land Use Plan (CLUP) and Comprehensive Development Plan (CDP)— the two central plans mandated by the Local Government Code.

\subsubsection{How Were Post-Disaster Time-Pressure and Intervention-Related Risk Management Balanced?}

The disaster catalysed the city government to respond quickly in a plan to resettle people acutely at-risk. Shortfalls, in terms of providing shelter, livelihoods, and access to basic services, may have been due to pressure to take immediate action before comprehensive planning took place, hence, rushing the process (CG10). For instance, land initially allocated for resettlement housing was later deemed to be at high risk from geological hazards (CG10). The land ultimately chosen (i.e., in Tacloban North) required additional infrastructure to connect new communities to downtown areas for services and livelihoods. Pressure led the resettlement process to begin without exploration of other alternatives [83].

Residents in some resettlement sites still live with inadequate infrastructure and services, few livelihood opportunities, and have had their social networks disrupted (CG10, CG14, RG2). Others have returned to informal settlements along the coast in order to regain access to fishing livelihoods (CG14). Four years on from the disaster, short-term goals, as described in the TRRP, remain partially unfulfilled. This is, potentially, due to the quality of both planning and implementation decisions, which are made with urgency under high pressure, leading to delays and ineffective, unsustainable recovery interventions. As is common in post-disaster contexts, time pressures limited the extent of risk and needs assessments and planning prior to action. However, such assessments should not be disregarded $[15,25,38]$ as even short-term decisions can have long-term resilience and development implications [87]. 


\subsection{Participation}

4.5.1. To What Extent and How Did Processes and Structures in Place Promote Collaboration over Competition?

The planning of the TRRP, institutionalised through an executive order by the Mayor, sought to be guided by principles of inclusiveness, collaboration, and participation, striving for, "national and local ownership and engaging all stakeholders especially the communities" (p. 5). The UN-Habitat provided a general framework for the structure of the TRRP, while the city government and other stakeholders, down to local level and local NGOs, provided the content (CG5, LG1). Participation in planning meetings and workshops appears to have been diverse; the TRRP lists more than 150 individuals from many sectors as participants.

Despite the structures in place, meaningful engagement and participation was challenging and insufficient (CG5, CG7, CG10). The opportunity to shape an important planning document failed to incentivise some. Furthermore, the visible role of an external organisation, i.e., UN-Habitat, negatively influenced perceptions of the TRRP for some (CG6). The resulting agreement was seen as a document created by the city mayor and the UN-Habitat rather than one created through an inclusive, city-led-and-owned process (CG7). The absence of a government mandate for the plan may have led some agencies to disregard its importance (CG7, NG2). Some city government departments stuck to traditional mandates and prioritised their own plans and visions (CG7, RG2). Challenges to establish a common vision among multiple stakeholders caused some to pursue projects independently (INGO5). Further, a power struggle emerged between organisations, political parties, NGOs, and INGOs, each protecting their own agendas, which was not beneficial to the affected communities (NGO1). Participation in a process that promoted, but did not incentivise, collaboration did not eliminate competition between actors.

\subsubsection{How Participatory Were Decision-Making Processes and Did Participation Challenge Power Structures?}

The decision-making power was centralised within the TRSDG, chaired by the mayor, with the UN-Habitat as co-chair. Conveners of the five sectoral clusters provided the information upon which decisions were made. The TRSDG also had a steering committee, with key officials and national government agencies. For instance, the National Housing Authority had decision-making power for building new homes. The national government also controlled the flow of funds down to the city level (CG5).

The planning process engaged national, city, and local government agencies, and other stakeholders, including NGOs, humanitarian actors, academics, religious leaders, and the private sector through planning charrettes, workshops, and meetings. Local leaders and NGOs represented affected people at the community level (LG1, LG2, INGO2) and community members themselves were only involved in some meetings (HA2). Following a three-month planning period, a public general assembly presented a draft TRRP to more than 1000 people (IGO1, CG8). People had the chance to ask questions, but had little opportunity to influence or change the plans (CG3, HA2). Some felt the specific needs of vulnerable groups were, generally, overlooked (INGO1). In 2015, part-way through the implementation of the TRRP, the mayor requested weekly meetings with relocated people to address their concerns, but the outcomes of these meetings are not clear (CG5).

The city faced challenges in the widening and deepening involvement in the decision-making process. In general, organisations and individuals with resources, power, and political influence had greater leverage in shaping decision-making processes (INGO1). An INGO representative recounted that actively providing input to the process took significant time and effort (INGO2), resources which were in high demand elsewhere at the time. Furthermore, some residents were reluctant to participate in local assembly meetings for fear of speaking publicly or out of embarrassment over illiteracy, which 
would be made evident by being seen to use a thumbmark in place of a signature when registering at a meeting (INGO1).

\section{Discussion}

The presented and tested typology framework aims to identify and articulate potential development-DRR trade-offs inherent in decision-making processes, ideally, before they take place. Following McShane et al. [18] and Howe et al. [19], we argue that identifying and making trade-offs, explicit from the outset, represent the first steps towards addressing these issues in decision-making and in transforming the relationship between development and DRR. Recognising trade-offs may or may not lead to a decrease in the competition among various goals or the elimination of trade-offs. However, identifying trade-offs and exploring the potential consequences of different possible decisions gives a better understanding of how risk is created. Further, this can lead to appropriate solutions to be deliberated amongst stakeholders for more equitable, resilient, and sustainable outcomes, thus, transforming the relationship between development and DRR [89].

In our case study application in Tacloban, Philippines, the typology framework trade-off dimensions and relevant key questions enabled the retrospective compilation of a narrative based on numerous stakeholder perspectives. This narrative reveals how DRR processes can not only reduce or restrict development, but also how DRR focused on a single hazard (i.e., typhoon risk) can fail to decrease multi-hazard disaster risk. In retrospect, a focus on the trade-off dimensions reveals misalignment of stakeholder perspectives and scales within a planning or decision-making process; a misalignment with tangible negative consequences. For example, some resettlement sites, though deemed safe from typhoon and storm surge impacts (a main goal of the recovery process), are not the communities that were envisioned four years on from the disaster, in terms of livelihoods, environment, and access to social services. Livelihood interventions have proved unsustainable because they overlooked the skills, needs, and wishes of the intended beneficiaries. Also, a disregard for the farming livelihoods when agricultural land was converted into settlements reflects the City's priorities, which has had negative consequences on jobs and food security. Meaningful, well-planned participation of stakeholders at multiple levels is crucial to understanding needs and preferences, and is essential for developing the capacity of stakeholders and gaining their buy-in for future plans [85].

The typology framework, as it is presented here, is a good basis for new analyses of trade-offs. Further study has the potential to refine the existing trade-off dimensions, identify additional dimensions, and better explore the interactions between these trade-offs. Looking ahead to future empirical testing of the typology framework, we suggest initiating applications at the start of decision-making processes (rather than retrospectively) for two reasons: (i) For greater access to stakeholders and information and (ii) to inform and shape the processes themselves, in real-time. Real-time application is likely to demand those with decision-making power to engage in self-reflection and acknowledge flaws in the status quo, which is a significant challenge [90]. However, the motivation remains that active consideration of trade-offs when making policy or planning decisions can help pursue development and DRR goals in mutually beneficial ways, which would represent a transformation [89].

Future testing may explore other DRR phases, i.e., mitigation, preparedness or response, or be applied to cross-cutting resilience interventions. For example, the typology might complement existing guidelines, such as UNISDR's Ten Essentials for Making Cities Resilient [91], by ensuring that social inclusion, participation, and equity are addressed and short- and long-term goals can be pursued without negative implications for each other. New analyses might also consider trade-offs in a range of different development contexts. For instance, the equity-efficiency trade-off may be more evident in contexts where disaster risk insurance coverage is more widespread and, thus, is deemed a legitimate risk prevention measure. 


\section{Conclusions}

Development continues to be an underlying driver of disaster risk despite increased recognition of this fact. The trade-off typology framework presented in this paper is a first attempt to organize and examine the various trade-offs that exist between development and DRR. The typology provides a framework through which five dimensions of trade-offs in decision-making can be examined, including aggregation, risk, equity, time, and participation. We tested this framework in Tacloban, Philippines, following Typhoon Haiyan (Yolanda), to understand the decision-making trade-offs in a major disaster recovery process.

We highlight the need to better understand and address the inherent trade-offs in decision-making, which involves looking deeper into how decisions are made at all levels and to what extent decision-making goals and processes at all levels align. Focusing on trade-offs moves interventions to reduce disaster risk upstream to the processes and inherent decisions which shape development and regulation. It acknowledges that disaster risk is created by those processes. Focusing on the trade-offs faced by decision-makers at all levels can, thus, help to identify a space for policy- or decision-making for a pro-active, rather than reactive, approach to DRR.

Author Contributions: H.T., M.B., G.H., and A.R. provided the overall framing. H.T. performed the literature review on trade-offs. H.T. and A.P. designed the field work and H.T. (analysis only), M.B., K.J., A.P., and L.L.M. collected and analysed the data. L.L.M. provided the local context for Tacloban and the Post-Yolanda recovery and redevelopment process.

Acknowledgments: We wish to acknowledge the financial support of the Swedish International Development Cooperation Agency (Sida). This work is part of the SEI Initiative on Transforming Development and Disaster Risk (TDDR). We specifically appreciate the support of Albert Salamanca, Frank Thomalla, Jon Ensor, John Forrester, Åsa Gerger Swartling, Ruth Butterfield, Martin Brown Munene (former colleague at SEI), and Mark Pelling (King's College London) for their participation in numerous discussions which have helped to clarify and strengthen the typology framework. Thank you also to Louis Lebel, who provided feedback in the early drafts of the manuscript, Karen Brandon who edited it, and the anonymous reviewers who provided excellent comments which have improved the paper.

Conflicts of Interest: The authors declare no conflict of interest.

\section{References}

1. White, G.F.; Kates, R.W.; Burton, I. Knowing better and losing even more: The use of knowledge in hazards management. Environ. Hazards 2001, 3, 81-92. [CrossRef]

2. The United Nations General Assembly (UNGA). Sendai Framework for Disaster Risk Reduction 2015-2030; UN: Sendai, Japan, 2015; p. 25.

3. IRDR. Disaster Risk Reduction and Sustainable Development; Integrated Research on Disaster Risk (IRDR): New York, NY, USA, 2014; p. 6.

4. Christoplos, I.; Rodríguez, T.; Schipper, E.L.F.; Narvaez, E.A.; Bayres Mejia, K.M.; Buitrago, R.; Gómez, L.; Pérez, F.J. Learning from recovery after Hurricane Mitch. Disasters 2010, 34, S202-S219. [CrossRef] [PubMed]

5. Ensor, M.O. (Ed.) The Legacy of Hurricane Mitch: Lessons from Post-Disaster Reconstruction in Honduras; University of Arizona Press: Tucson, AZ, USA, 2009; ISBN 978-0-8165-2784-7.

6. Thomalla, F.; Lebel, L.; Boyland, M.; Marks, D.; Kimkong, H.; Tan, S.B.; Nugroho, A. Long-term recovery narratives following major disasters in Southeast Asia. Reg. Environ. Chang. 2018, 18, 1211-1222. [CrossRef]

7. Enarson, E.; Fothergill, A.; Peek, L. Gender and Disaster: Foundations and Directions. In Handbook of Disaster Research; Rodríguez, H., Quarantelli, E.L., Dynes, R.R., Eds.; Handbooks of Sociology and Social Research; Springer: New York, NY, USA, 2007; ISBN 978-0-387-73952-6.8.

8. Peek, L.; Stough, L.M. Children with Disabilities in the Context of Disaster: A Social Vulnerability Perspective. Child Dev. 2010, 81, 1260-1270. [CrossRef] [PubMed]

9. Cutter, S.L. The forgotten casualties redux: Women, children, and disaster risk. Glob. Environ. Chang. 2017, 42, 117-121. [CrossRef]

10. Gartrell, A.; Hoban, E. Structural Vulnerability, Disability, and Access to Nongovernmental Organization Services in Rural Cambodia. J. Soc. Work Disabil. Rehabil. 2013, 12, 194-212. [CrossRef] [PubMed] 
11. Rodriguez-Oreggia, E.; De La Fuente, A.; De La Torre, R.; Moreno, H.A. Natural Disasters, Human Development and Poverty at the Municipal Level in Mexico. J. Dev. Stud. 2013, 49, 442-455. [CrossRef]

12. Benson, C. Indirect Economic Impacts of Disasters; Government Office for Science: London, UK, 2012.

13. World Bank. World Development Report 2014: Risk and Opportunity_Managing Risk for Development; World Development Report; The World Bank: Washington, DC, USA, 2014; p. 362.

14. United Nations (UN). Transforming Our World: The 2030 Agenda for Sustainable Development; United Nations: New York, NY, USA, 2015; p. 41.

15. The United Nations Office for Disaster Risk Reduction (UNISDR). Making Development Sustainable: The Future of Disaster Risk Management; 2015 Global Assessment Report on Disaster Risk Reduction; UNISDR: Geneva, Switzerland, 2015; p. 316.

16. Fama, E.F.; French, K.R. Testing Trade-Off and Pecking Order Predictions about Dividends and Debt. Rev. Financ. Stud. 2002, 15, 1-33. [CrossRef]

17. Hahn, T.; Figge, F.; Pinkse, J.; Preuss, L. Trade-offs in corporate sustainability: You can't have your cake and eat it: Trade-Offs in Corporate Sustainability: You Can't Have Your Cake and Eat It. Bus. Strategy Environ. 2010, 19, 217-229. [CrossRef]

18. McShane, T.O.; Hirsch, P.D.; Trung, T.C.; Songorwa, A.N.; Kinzig, A.; Monteferri, B.; Mutekanga, D.; Thang, H.V.; Dammert, J.L.; Pulgar-Vidal, M.; et al. Hard choices: Making trade-offs between biodiversity conservation and human well-being. Biol. Conserv. 2011, 144, 966-972. [CrossRef]

19. Howe, C.; Suich, H.; Vira, B.; Mace, G.M. Creating win-wins from trade-offs? Ecosystem services for human well-being: A meta-analysis of ecosystem service trade-offs and synergies in the real world. Glob. Environ. Chang. 2014, 28, 263-275. [CrossRef]

20. Rodríguez, J.; Beard, J.; Bennett, E.; Cumming, G.; Cork, S.; Agard, J.; Dobson, A.; Peterson, G. Trade-offs across Space, Time, and Ecosystem Services. Ecol. Soc. 2006, 11, 28. [CrossRef]

21. Kharas, H. Trade-Offs in Sustainable Development. In Practicing Sustainability; Madhavan, G., Oakley, B., Green, D., Koon, D., Low, P., Eds.; Springer: New York, NY, USA, 2013; pp. 19-23. ISBN 978-1-4614-4348-3.

22. Nilsson, M.; Griggs, D.; Visbeck, M. Policy: Map the interactions between Sustainable Development Goals. Nature 2016, 534, 320-322. [CrossRef] [PubMed]

23. Luu, C.; Von Meding, J.; Kanjanabootra, S. Balancing costs and benefits in Vietnam's hydropower industry: A strategic proposal. Int. J. Disaster Resil. Built Environ. 2017, 8, 27-39. [CrossRef]

24. Lebel, L.; Sinh, B.T.; Garden, P.; Seng, S.; Tuan, L.A.; Truc, D.V. Promise of flood protection: Dikes and dams, drains and diversions. In Contested Waterscapes in the Mekong Region: Hydropower, Livelihoods and Governance; Molle, F., Foran, T., Kakonen, M., Eds.; Earthscan: London, UK, 2009; ISBN 978-1-84977-086-6.

25. United Nations Office for Disaster Reduction (UNISDR). 2011 Global Assessment Report on Disaster Risk Reduction: Revealing Risk Redefining Development; United Nations Office for Disaster Reduction (UNISDR): Geneva, Switzerland, 2011.

26. Munich Re. Natural Catastrophe Review: Series of Hurricanes Makes 2017 Year of Highest Insured Losses Ever. Available online: https://www.munichre.com/en/media-relations/publications/press-releases/ 2018/2018-01-04-press-release/index.html (accessed on 26 March 2018).

27. OECD. Boosting Disaster Prevention through Innovative Risk Governance: Insights from Austria, France, and Switzerland; OECD Reviews of Risk Management Policies; OECD: Paris, France, 2017.

28. Filatova, T.; Van Der Veen, A.; Parker, D.C. Land market interactions between heterogeneous agents in a heterogeneous Landscape-Tracing the macro-scale effects of individual trade-offs between environmental amenities and disamenities. Can. J. Agric. Econ. 2009, 57, 431-457. [CrossRef]

29. Booth, K.; Harwood, A. Insurance as catastrophe: A geography of house and contents insurance in bushfire-prone places. Geoforum 2016, 69, 44-52. [CrossRef]

30. Azimi, N.; Asgary, A. Rural residents and choice of building earthquake-resistant house: Results of a choice experiment study. Environ. Hazards 2013, 12, 240-257. [CrossRef]

31. Clarke, D.J.; Grenham, D. Microinsurance and natural disasters: Challenges and options. Environ. Sci. Policy 2013, 27, S89-S98. [CrossRef]

32. Lall, S.V.; Deichmann, U. Density and Disasters: Economics of Urban Hazard Risk. World Bank Res. Obs. 2012, 27, 74-105. [CrossRef]

33. Lall, S.V.; Deichmann, U. Density and Disasters: Economics of Urban Hazard Risk; The World Bank: Washington, DC, USA, 2009. 
34. Hudson, P.; Botzen, W.J.W.; Feyen, L.; Aerts, J.C.J.H. Incentivising flood risk adaptation through risk based insurance premiums: Trade-offs between affordability and risk reduction. Ecol. Econ. 2016, 125, 1-13. [CrossRef]

35. Davis, L.; Whitehouse, R.; Maierson, E. As Harvey Raged, Their Homes Were Swamped on Purpose. Six Months Later, They Face a Terrible Choice. The New York Times, 19 March 2018.

36. Gaillard, J.-C. Alternative paradigms of volcanic risk perception: The case of Mt. Pinatubo in the Philippines. J. Volcanol. Geotherm. Res. 2008, 172, 315-328. [CrossRef]

37. Tschakert, P.; Barnett, J.; Ellis, N.; Lawrence, C.; Tuana, N.; New, M.; Elrick-Barr, C.; Pandit, R.; Pannell, D. Climate change and loss, as if people mattered: Values, places, and experiences: Climate change and loss, as if people mattered. Wiley Interdiscip. Rev. Clim. Chang. 2017, 8, e476. [CrossRef]

38. The United Nations Office for Disaster Risk Reduction (UNISDR). Global Assessment Report on Disaster Risk Reduction 2013; From Shared Risk to Shared Value: The Business Case for Disaster Risk Reduction; UNISDR: Geneva, Switzerland, 2013.

39. Sudmeier-Rieux, K.; Fra.Paleo, U.; Garschagen, M.; Estrella, M.; Renaud, F.G.; Jaboyedoff, M. Opportunities, incentives and challenges to risk sensitive land use planning: Lessons from Nepal, Spain and Vietnam. Int. J. Disaster Risk Reduct. 2015, 14, 205-224. [CrossRef]

40. Han, G.; Kasperson, R.E. Dilemmas and pathways to dealing with flood problems in twenty-first century China. Int. J. Disaster Risk Sci. 2011, 2, 21-30. [CrossRef]

41. Devisscher, T.; Boyd, E.; Malhi, Y. Anticipating future risk in social-ecological systems using fuzzy cognitive mapping: The case of wildfire in the Chiquitania, Bolivia. Ecol. Soc. 2016, 21, 18. [CrossRef]

42. Nicholls, R.J.; Hanson, S.; Herweijer, C.; Patmore, N.; Hallegatte, S.; Corfee-Morlot, J.; Château, J.; Muir-Wood, R. Ranking Port Cities with High Exposure and Vulnerability to Climate Extremes; Organisation for Economic Co-operation and Development: Paris, France, 2008.

43. Crick, F.; Jenkins, K.; Surminski, S. Strengthening insurance partnerships in the face of climate change-Insights from an agent-based model of flood insurance in the UK. Sci. Total Environ. 2018, 636, 192-204. [CrossRef] [PubMed]

44. OECD. Improving the Evidence Base on the Cost of Disasters; OECD: Paris, France, 2017.

45. Eiser, J.R.; Bostrom, A.; Burton, I.; Johnston, D.M.; McClure, J.; Paton, D.; der Pligt, J.; White, M.P. Risk interpretation and action: A conceptual framework for responses to natural hazards. Int. J. Disaster Risk Reduct. 2012, 1, 5-16. [CrossRef]

46. OECD. Boosting Resilience through Innvoative Risk Governance; OECD Reviews of Risk Management Policies; OECD: Paris, France, 2014.

47. Ishtiaque, A.; Sangwan, N.; Yu, D.J. Robust-yet-fragile nature of partly engineered social-ecological systems: A case study of coastal Bangladesh. Ecol. Soc. 2017, 22, 5. [CrossRef]

48. UNISDR. 2009 Global Assessment Report on Disaster Risk Reduction: Risk and Poverty in a Changing Climate Invest Today for a Safer Tomorrow; United Nations: Geneva, Switzerland, 2009.

49. Oven, K.J.; Rigg, J.D. The Best of Intentions? Managing Disasters and Constructions of Risk and Vulnerability in Asia. Asian J. Soc. Sci. 2015, 43, 685-712. [CrossRef]

50. Dilling, L.; Daly, M.E.; Travis, W.R.; Wilhelmi, O.V.; Klein, R.A. The dynamics of vulnerability: Why adapting to climate variability will not always prepare us for climate change. Wiley Interdiscip. Rev. Clim. Chang. 2015, 6, 413-425. [CrossRef]

51. Yu, D.J.; Sangwan, N.; Sung, K.; Chen, X.; Merwade, V. Incorporating institutions and collective action into a sociohydrological model of flood resilience. Water Resour. Res. 2017, 53, 1336-1353. [CrossRef]

52. Linkov, I.; Bridges, T.; Creutzig, F.; Decker, J.; Fox-Lent, C.; Kröger, W.; Lambert, J.; Levermann, A.; Montreuil, B.; Nathawani, J.; et al. Commentary: Changing the resilience paradigm. Nat. Clim. Chang. 2014, 4, 407-409. [CrossRef]

53. Kappes, M.S.; Keiler, M.; von Elverfeldt, K.; Glade, T. Challenges of analyzing multi-hazard risk: A review. Nat. Hazards 2012, 64, 1925-1958. [CrossRef]

54. Lebel, L.; Manuta, J.B.; Garden, P. Institutional traps and vulnerability to changes in climate and flood regimes in Thailand. Reg. Environ. Chang. 2011, 11, 45-58. [CrossRef]

55. Thomalla, F.; Smith, R.; Schipper, E.L.F. Cultural Aspects of Risk to Environmental Changes and Hazards: A Review of Perspectives. In The Impact of Disasters on Livelihoods and Cultural Survival: Opportunities, Losses, and Mitigation; Companion, M., Ed.; CRC Press: Boca Raton, FL, USA, 2015. 
56. Nathan, F. Risk perception, risk management and vulnerability to landslides in the hill slopes in the city of La Paz, Bolivia. A preliminary statement. Disasters 2008, 32, 337-357. [CrossRef] [PubMed]

57. Roberts, J. The Deconstruction of Volcanic Risk, Ca: Galeras, Colombia; University of York: York, UK, 2015.

58. Cannon, T.; Müller-Mahn, D. Vulnerability, resilience and development discourses in context of climate change. Nat. Hazards 2010, 55, 621-635. [CrossRef]

59. Oxford University Press English Oxford Living Dictionaries: Equitable. Available online: https://en. oxforddictionaries.com/definition/equitable (accessed on 17 March 2018).

60. Bahadur, A.V.; Ibrahim, M.; Tanner, T. Characterising resilience: Unpacking the concept for tackling climate change and development. Clim. Dev. 2013, 5, 55-65. [CrossRef]

61. Beckman, M. Converging and conflicting interests in adaptation to environmental change in central Vietnam. Clim. Dev. 2011, 3, 32-41. [CrossRef]

62. Rigg, J.; Oven, K. Building liberal resilience? A critical review from developing rural Asia. Glob. Environ. Chang. 2015, 32, 175-186. [CrossRef]

63. Ahmad, M. Economic Freedom and Income Inequality: Does Political Regime Matter? Economies 2017, 5, 18. [CrossRef]

64. Chronic Poverty Research Center. The Chronic Poverty Report 2008-09: Escaping Poverty Traps; Chronic Poverty Research Center: London, UK, 2008.

65. Leon, E.; Kelman, I.; Kennedy, J.; Ashmore, J. Capacity building lessons from a decade of transitional settlement and shelter. Int. J. Strateg. Prop. Manag. 2009, 13, 247-265. [CrossRef]

66. Goodspeed, T.J.; Haughwout, A.F. On the optimal design of disaster insurance in a federation. Econ. Gov. 2012, 13, 1-27. [CrossRef]

67. Picard, P. Natural disaster insurance and the equity-efficiency trade-off. J. Risk Insur. 2008, 75, 17. [CrossRef]

68. Hallegatte, S.; Vogt-Schilb, A.; Bangalore, M.; Rozenberg, J. Unbreakable: Building the Resilience of the Poor in the Face of Natural Disasters; Climate Change and Development Series; World Bank Group: Washington, DC, USA, 2017; ISBN 978-1-4648-1004-6.

69. Patankar, A. The Exposure, Vulnerability, and Ability to Respond of Poor Households to Recurrent Floods in Mumbai; Policy Research Working Paper; World Bank Group: Washington, DC, USA, 2015.

70. Gall, M.; Cutter, S.L.; Nguyen, K. Transformative Development and Disaster Risk Management; Integrated Research on Disaster Risk: Beijing, China, 2014; p. 44.

71. Wisner, B.; Blaikie, P.; Cannon, T.; Davis, I. At Risk: Natural Hazards, People's Vulnerability and Disasters (Part I); Routledge: Abingdon, UK, 2004; ISBN 978-0-415-25215-7.

72. Hallegatte, S. How Economic Growth and Rational Decisions Can Make Disaster Losses Grow Faster Than Wealth; World Bank: Washington, DC, USA, 2011.

73. Flechas, J.; Staletovich, J. Miami Beach's Battle to Stem Rising Tides. Miami Her. 23 October 2015. Available online: http://www.miamiherald.com/news/local/community/miami-dade/miami-beach/ article41141856.html (accessed on 7 June 2018).

74. Vorhies, F. The Economics of Public Sector Investment in Disaster Risk Reduction. A Working Paper Based on a Review of Current Literature Prepared for the UNISDR; Education for Safety, Resilience and Social Cohesion: Paris, France, 2012.

75. Mullin, M.; Rubado, M.E. Local Response to Water Crisis: Explaining Variation in Usage Restrictions During a Texas Drought. Urban Aff. Rev. 2017, 53, 752-774. [CrossRef]

76. Fengler, W. Managing Post-Disaster Reconstruction Finance-International Experience in Public Financial Management; World Bank: Washington, DC, USA, 2008.

77. Neumayer, E.; Plümper, T.; Barthel, F. The political economy of natural disaster damage. Glob. Environ. Chang. 2014, 24, 8-19. [CrossRef]

78. Hardoy, J.; Pandiella, G.; Barrero, L.S.V. Local disaster risk reduction in Latin American urban areas. Environ. Urban. 2011, 23, 401-413. [CrossRef]

79. Badri, S.A.; Asgary, A.; Eftekhari, A.R.; Levy, J. Post-disaster resettlement, development and change: A case study of the 1990 Manjil earthquake in Iran: Post-Disaster Resettlement, Development and Change. Disasters 2006, 30, 451-468. [CrossRef] [PubMed]

80. Ganapati, N.E.; Ganapati, S. Enabling Participatory Planning after Disasters: A Case Study of the World Bank's Housing Reconstruction in Turkey. J. Am. Plan. Assoc. 2008, 75, 41-59. [CrossRef] 
81. Mannakkara, S.; Wilkinson, S.J. Supporting post-disaster social recovery to build back better. Int. J. Disaster Resil. Built Environ. 2015, 6, 126-139. [CrossRef]

82. Bavinck, M.; de Klerk, L.; van der Plaat, F.; Ravesteijn, J.; Angel, D.; Arendsen, H.; van Dijk, T.; de Hoog, I.; van Koolwijk, A.; Tuijtel, S.; et al. Post-tsunami relocation of fisher settlements in South Asia: Evidence from the Coromandel Coast, India. Disasters 2015, 39, 592-609. [CrossRef] [PubMed]

83. Parker, E.; Maynard, V.; Garcia, D.; Yoseph-Paulus, R. Urban Planning Following Humanitarian Crises: Supporting Local Government to Take the Lead in the Philippines Following Super Typhoon Haiyan; IIED: London, UK, 2017.

84. Schilderman, T.; Lyons, M. Resilient dwellings or resilient people? Towards people-centred reconstruction. Environ. Hazards-Hum. Policy Dimens. 2011, 10, 218-231. [CrossRef]

85. Scolobig, A.; Prior, T.; Schröter, D.; Jörin, J.; Patt, A. Towards people-centred approaches for effective disaster risk management: Balancing rhetoric with reality. Int. J. Disaster Risk Reduct. 2015, 12, 202-212. [CrossRef]

86. Republic of the Philippines National Disaster Risk Reduction and Management Council. NDRRMC Update: Final Report re Effects of Typhoon "Yolanda" (Haiyan). 2013. Available online: http:/ /www.ndrrmc.gov.ph/ 21-disaster-events /1329-situational-report-re-effects-of-typhoon-yolanda-haiyan (accessed on 7 June 2018).

87. City Government of Tacloban, Republic of the Phillipines. The Tacloban Recovery and Rehabilitation Plan; City Government of Tacloban, Republic of the Phillipines: Tacloban, Phillipines, 2014.

88. Ingram, J.C.; Franco, G.; Rio, C.R.; Khazai, B. Post-disaster recovery dilemmas: Challenges in balancing short-term and long-term needs for vulnerability reduction. Environ. Sci. Policy 2006, 9, 607-613. [CrossRef]

89. Thomalla, F.; Boyland, M.; Johnson, K.; Ensor, J.; Tuhkanen, H.; Gerger Swartling, Å.; Han, G.; Forrester, J.; Wahl, D. Transforming Development and Disaster Risk. Sustainability 2018, 10, 1458. [CrossRef]

90. Galafassi, D.; Daw, T.M.; Munyi, L.; Brown, K.; Barnaud, C.; Fazey, I. Learning about social-ecological trade-offs. Ecol. Soc. 2017, 22, 2. [CrossRef]

91. United Nations Office for Disaster Reduction (UNISDR). How To Make Cities More Resilient: A Handbook For Local Government Leaders; United Nations Office for Disaster Reduction (UNISDR): Geneva, Switzerland, 2012; p. 100.

(C) 2018 by the authors. Licensee MDPI, Basel, Switzerland. This article is an open access article distributed under the terms and conditions of the Creative Commons Attribution (CC BY) license (http:/ / creativecommons.org/licenses/by/4.0/). 